\title{
$W$ mutant mice with mild or severe developmental defects contain distinct point mutations in the kinase domain of the c-kit receptor
}

\author{
Alastair D. Reith, Robert Rottapel, Elizabeth Giddens, Claire Brady, Lesley Forrester, and \\ Alan Bernstein ${ }^{1,2}$ \\ Division of Molecular and Developmental Biology, Mount Sinai Hospital Research Institute, Toronto, Ontario M5G 1X5, \\ Canada; ${ }^{1}$ Department of Medical Genetics, University of Toronto, Toronto Canada
}

\begin{abstract}
Mutations at the mouse $W / c-k i t$ locus lead to intrinsic defects in stem cells of the melanocytic, hematopoietic, and germ cell lineages. $W$ alleles vary in the overall severity of phenotype that they confer, and some alleles exhibit an independence of pleiotropic effects. To elucidate the molecular basis for these biological differences, we analyzed the c-kit locus and the c-kit-associated autophosphorylation activities in five different $W$ mutants representative of a range of $W$ phenotypes. Mast cell cultures derived from mice or embryos homozygous for each $W$ allele were deficient in c-kit autophosphorylation activity, the extent of which paralleled the severity of phenotype conferred by a given $W$ allele both in vivo and in an in vitro mast cell coculture assay. The mildly dominant, homozygous viable alleles $W^{44}$ and $W^{57}$ were found to express reduced levels of an apparently normal c-kit protein. In contrast, c-kit kinase defects conferred by the moderately dominant, homozygous viable alleles $W^{41}$ or $W^{55}$ or the homozygous lethal allele, $W^{37}$, were attributed to single-point mutations within the kinase domain of the c-kit polypeptide, which result in point substitutions of amino acid residues highly conserved in the family of protein tyrosine kinases. The nature and location of these amino acid substitutions account for the relative severity of phenotypes conferred by these $W$ alleles and demonstrate that the pleiotropic developmental defects associated with the $\mathrm{W} / \mathrm{c}-\mathrm{kit}$ locus arise as the result of dominant loss-of-function mutations in a transmembrane receptor tyrosine kinase.
\end{abstract}

[Key Words: c-kit tyrosine kinase; W locus; dominant-negative mutations]

Received November 6, 1989; revised version accepted December 19, 1989.

The mechanisms that underlie the determination of cell fate and cell lineage during mammalian development remain to be determined. In Drosophila, progress toward an understanding of the strategies utilized by multicellular organisms to ensure orderly development has derived largely from the molecular analysis of the genes responsible for various developmental mutations. This has revealed a limited number of protein families that are involved in developmental decisions. Included among these are proteins with tyrosine kinase activity. Tyrosine kinases were identified initially as the products of various oncogenes. They can be divided into those that are associated with the cytoplasmic aspect of the cell membrane and transmembrane receptors that have a single membrane-spanning domain (for review, see Hanks et al. 1988; Yarden and Ullrich 1988). This latter group of proteins are thought to play important roles in transduction of extracellular signals to the cytoplasm by means of ligand-receptor interactions at the

\footnotetext{
${ }^{2}$ Corresponding author.
}

cell surface, activating the intracellular tyrosine kinase domain. The potential of these molecules to mediate intercellular signaling, along with the high degree of evolutionary conservation of this gene family, suggests that receptor tyrosine kinases play important roles in cellcell communication during embryonic development of multicellular organisms.

Consistent with this hypothesis, distinct developmental abnormalities have been found to result from mutation of receptor tyrosine kinases. For example, sevenless is a cell autonomous homeotic mutation that results in the failure of undifferentiated cells to detect and respond to positional cues to differentiate to the $\mathrm{R} 7$ photoreceptor within each ommatidium of the compound eye (Tomlinson and Ready 1987). The sevenless gene has been isolated and shown to be the Drosophila homolog of the proto-oncogene c-ros, a member of the receptor tyrosine kinase gene family (Hafen et al. 1987). Similarly, mutations in another transmembrane protein tyrosine kinase, the Drosophila epidermal growth factor (EGF) receptor homolog (DER) gene, have been found to 
result in abnormal egg development (Price et al. 1989; Schejter and Shilo 1989) and to affect differentiation of ommatidia in compound eye development (Baker and Rubin 1989). Torso, mutation of which affects pattern formation in the early Drosophila embryo, has also been shown to encode a receptor tyrosine kinase (Sprenger et al. 1989|.

In mammalian systems, genetic analysis of the roles played by tyrosine kinases in development has been hampered by the paucity of known germ line mutations in these genes. We have shown recently that the protooncogene c-kit, which encodes a transmembrane receptor tyrosine kinase, maps to the mouse $W$ locus (Chabot et al. 1988). Moreover, genomic rearrangements within the c-kit locus have been reported for two $W$ alleles (Geissler et al. 1988), and the kinase activity associated with the c-kit receptor is impaired in mast cell cultures derived from $W / W^{v}$ mutant mice (Nocka et al. 1989; Bernstein et al. 1990). These data, along with the demonstration that c-kit is expressed in those cell lineages affected by mutations at the $W$ locus (André et al. 1989; Nocka et al. 1989; Bernstein et al. 1990) have provided strong evidence that $W$ and c-kit are allelic.

Mutations at the murine dominant white spotting $(W)$ locus (Little 1915) have pleiotropic effects on the development of hematopoietic, melanocyte, and germ cell lineages (for reviews, see Russell 1979; Silvers 1979). A large number of $W$ alleles have been independently isolated that not only vary in the overall severity of the mutant phenotype but also exhibit an independence of pleiotropic effects (Table 1). By definition, melanogenesis is affected in animals heterozygous for any allele at the $W$ locus, although the extent of white spotting can vary. Some $W$ alleles are lethal in the homozygous state, with embryos being severely anemic and dying at or near parturition despite having normal hematocrits in the heterozygous condition. In contrast, some homozygous viable $W$ mutants have a relatively mild anemia both as heterozygotes and homozygotes. Although fertility is generally not affected in heterozygotes, some, but not all, homozygous viable $W$ mutants are sterile (Table 1 ). Mosaic analysis using either reciprocal bone marrow transplantation or embryonic chimeras has established that $W$ mutations do not result in defective environmental signals but affect the ability of stem cells within the hematopoietic, melanocyte, and germ cell lineages to respond correctly to such cues (Russell 1979).

To facilitate an understanding of the molecular basis of distinct $W$ phenotypes, we analyzed the structure and activity of c-kit in a number of independent and spontaneous $W$ alleles that confer a wide range of mutant phenotypes. We show that all of these mutations result in a deficiency in c-kit-associated kinase activity, either as the consequence of mutations that affect c-kit gene expression or point mutations that reside in highly conserved regions of the c-kit kinase domain. The nature of these amino acid substitutions correlates with the severity of phenotype conferred by each $W$ allele. We also describe a cell culture system in which the relative severities of $W$ mutations in vivo are reflected in vitro. The ability to analyze the biological and biochemical consequences of germ line mutations in a mammalian transmembrane receptor tyrosine kinase provides a unique opportunity to address the mechanisms of signal transduction by such proteins in a developmental context, without being restricted to only those mutations that affect their oncogenicity.

\section{Results \\ The overall severity of different $\mathrm{W}$ alleles can be reproduced in vitro by a mast cell coculture assay}

Homogenous populations of mast cells can be generated in vitro by suspension culture in the presence of an exogenous source of interleukin-3 (IL-3) (for review, see Schrader 1986). An alternate mode of mast cell growth has been described (Fujita et al. 1988b) that has no requirement for exogenous growth factors but is dependent on contact with embryonic fibroblasts. $W / W^{\mathrm{v}}$ mast cell cultures show normal proliferation in suspension culture but are deficient in fibroblast-dependent growth, a result of a defect in transition from $G_{1}$ to $S$ phase of the cell cycle (Fujita et al. 1988a).

Table 1. Pleiotropic effects of various $\mathrm{W}$ mutations

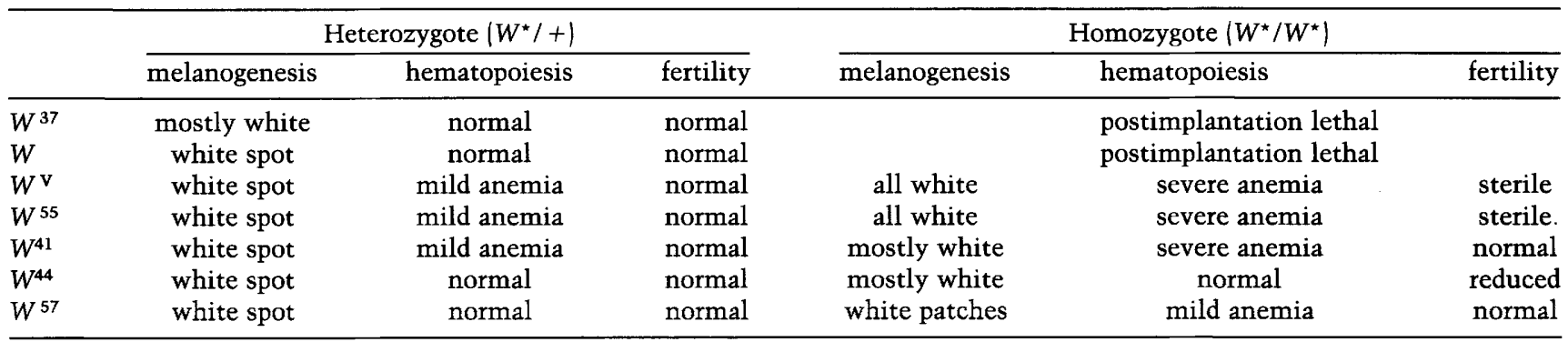

The phenotypic effects of various $W$ alleles on melanogenesis, hematopoiesis, and gametogenesis are shown. The alleles are listed in order of decreasing severity. $W$ (Little 1915) and $W^{37}$ (Geissler et al. 1981) are spontaneous mutants, with homozygotes having a severe macrocytic anemia detectable at mid-gestation and dying at, or near, parturition. $W^{\mathbf{v}}$ (Little and Cloudman 1937), $W^{44}, W^{41}$ (Geissler et al. 1981), $W^{55}$, and $W^{57}$ (J. Barker, pers. comm.; data not shown) are all spontaneous homozygous viable mutants. 


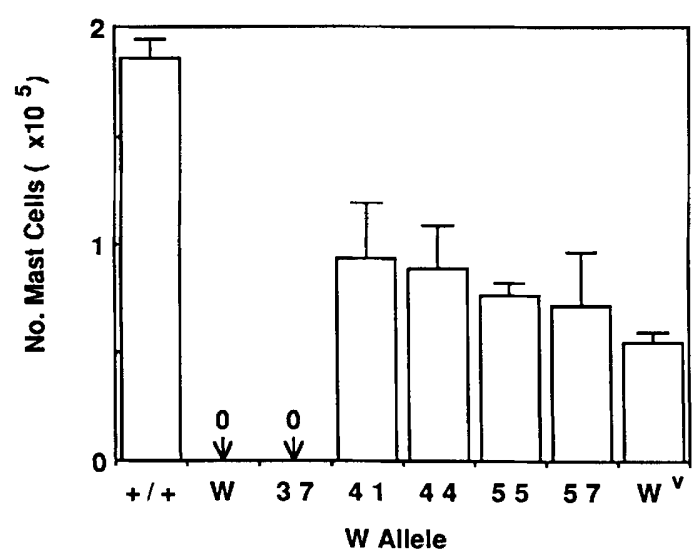

Figure 1. Maintenance in coculture of mast cells homozygous for various mutant $W$ alleles. Mast cells derived from fetal livers or aduit bone marrow of $+1+, W / W(W), W^{37} / W^{37}(37)$, $W^{41} / W^{41}(41), W^{44} / W^{44}(44), W^{55} / W^{55} \quad(55), W^{57} / W^{57}(57)$, or $W^{v /} W^{v}\left(W^{v}\right)$ animals were seeded onto confluent fibroblast monolayers. Cocultures were harvested and counted after 8 days. Results shown are the means ( \pm S.D.) of three independent cocultures. No mast cells were detected in cocultures set up with mast cells derived from $W / W$ or $W^{37} / W^{37}$ embryos.

Mast cell cultures derived from bone marrow or fetal liver of mouse strains $\mathrm{WB} / \mathrm{Re} W / W$ and $\mathrm{C} 57 \mathrm{BL} / 6+1+$, $W / W^{v}, W^{37} / W^{37}, W^{41} / W^{41}, W^{44} / W^{44}, W^{55} / W^{55}$ or $W^{57} / W^{57}$ were found to proliferate at similar rates in suspension culture in the presence of exogenous IL-3 (data not shown). However, as seen in Figure 1, markedly different growth properties were observed in the fibroblast coculture assay. After 8 days in coculture, a decrease in mast cell viability was apparent in cultures derived from the homozygous viable mutants $W^{41}, W^{44}, W^{55}, W^{57}$, and the viable compound heterozygote $W / W^{\nu}$, relative to mast cells from normal mice. In contrast, mast cell cultures derived from the fetal liver of embryos homozygous for the severe alleles $W$ and $W^{37}$ were unable to survive in coculture with normal fibroblasts. Thus, the mast cell coculture assay reflected the relative severity of phenotypes conferred by different $W$ alleles on the whole organism.

Both severe and mild $\mathrm{W}$ mutations confer deficiencies in c-kit in vitro autophosphorylation activity

Mast cells from normal mice contain two glycosylated forms of c-kit with molecular weights of 160 and 124 $\mathrm{kD}$, both of which have in vitro kinase activity (Nocka et al. 1989; Bernstein et al. 1990). In contrast, mast cells derived from adult bone marrow of $W / W^{V}$ animals, despite expressing normal levels of both glycosylated forms, are deficient in c-kit kinase activity (Nocka et al. 1989; Bernstein et al. 1990). Antiserum raised against a TrpE-kit fusion protein containing part of the intracellular domain of murine c-kit was used to assess any quantitative or qualitative changes in c-kit protein expression in mast cell cultures homozygous for the lethal allele $W^{37}$ or the viable $W$ alleles, $W^{41}, W^{44}, W^{55}$, and $W^{57}$.

Three patterns of expression were observed. First, approximately equivalent amounts of c-kit protein were observed in mast cells derived from the bone marrows of $+1+$ mice and mice homozygous for the mild alleles $W^{41}$ and $W^{55}$ (Fig. 2A). In contrast, mast cells homozygous for the $W^{44}$ or $W^{57}$ mutations contained much lower amounts of $\mathrm{c}$-kit protein, suggesting that these $W$ alleles confer quantitative changes in c-kit expression. A third pattern of c-kit expression was found with $W^{37} / W^{37}$ mast cells in which an alteration in the relative abundance of the two glycosylated forms of c-kit was observed, although the total amount of immunoprecipitable c-kit protein was similar to that found in $+/+$ mast cells. This difference cannot be attributed to the fetal origin of these cultures, as mast cell populations isolated
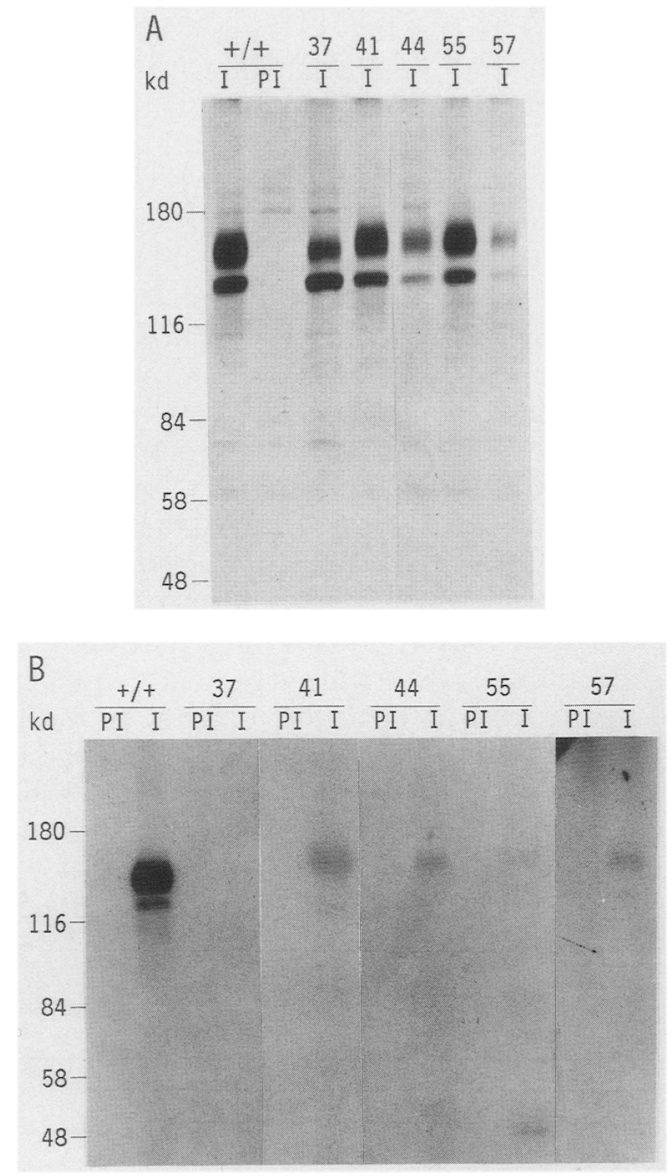

Figure 2. $W$ mutant mast cells are deficient in c-kit kinase activity. (A) Mast cell cultures homozygous for C57BL/6 +1+ and $W^{37}(37), W^{41}(41), W^{44}(44), W^{55}(55)$, and $W^{57}(57)$ mutant alleles were metabolically labeled with $\left[{ }^{35} S\right]$ methionine, and cell lysates immunoprecipitated with preimmune (PI) or c-kit specific immune (I) antisera prior to $7.5 \%$ SDS-PAGE and autoradiography. $|B|$ In vitro kinase assays using $\left[\gamma^{-32}{ }^{32}\right]$ ATP were performed on immunoprecipitates of the same mast cell cultures as those in $A$ prior to $7.5 \%$ SDS-PAGE and autoradiography. 
from the fetal livers of mice not carrying the $W^{37}$ allele expressed both forms of c-kit in a ratio similar to that observed in mast cells derived from adult bone marrow (data not shown).

To determine whether these different $W$ mutations affected c-kit-associated kinase activity, in vitro autophosphorylation assays were performed on c-kit protein immunoprecipitated from mast cell cultures. Three patterns of c-kit activity were observed: (1) The decreased levels of c-kit protein in $W^{44} / W^{44}$ and $W^{57} / W^{57}$ mast cells were reflected by a proportionate decrease in c-kit autophosphorylation activity (Fig. 2B); (2) the levels of c-kitassociated kinase activity were markedly reduced in mast cells derived from the homozygous viable mutants $W^{41}$ and $W^{55}$ (Fig. $2 B$ ); and (3) no kinase activity associated with either the 160 - or $124-\mathrm{kD}$ c-kit proteins was detectable in $W^{37} / W^{37}$ mast cell cultures (Fig. 2B).

$\mathrm{W}^{37}, \mathrm{~W}^{55}$, and $\mathrm{W}^{41}$ alleles contain point mutations in the $c$-kit tyrosine kinase domain

Southern blot analyses failed to detect genomic rearrangements of c-kit in $W^{37}, W^{55}$, or $W^{41}$ alleles /data not shown|, suggesting that the molecular basis for the deficiencies in these $W$ mutants lay in point mutations or small deletions/insertions in the c-kit coding sequence. To identify such changes, $c-k i t$ cDNA was cloned from cell types homozygous for each of these $W$ mutations by means of polymerase chain reaction (PCR) using a series of c-kit-specific oligonucleotide pairs (Fig. 3A). When compared with the published murine c-kit cDNA sequence (Qui et al. 1988), nucleotide sequence analyses of cDNA clones revealed single GC $\rightarrow$ AT transitions in the $c-k i t$ coding sequence that result in distinct amino acid substitutions in the c-kit polypeptide in each of these three $W$ alleles (Fig. 3B-D). Glu ${ }^{582}$ is mutated to lysine in $W^{37}$, whereas methionine replaces threonine at residue 660 in $W^{55}$. Both of these point mutations lie within or near the ATP-binding pocket of the c-kit kinase domain. Val ${ }^{831}$ within the phosphotransferase domain of the c-kit protein is mutated to methionine in $W^{41}$ (Fig. 3D). All of the mutations described above were found consistently in a total of six $\left(W^{37}\right)$, four $\left(W^{55}\right)$, and seven $\left(W^{41}\right)$ clones analyzed from two independent PCR reactions for each given $W$ allele and were never found in c-kit cDNA clones generated from other $W$ alleles.

Two other substitutions were detected in our c-kit nucleotide sequences compared with the sequence published previously for BALB/c brain cDNA /Qui et al. 1988). A GC $\rightarrow$ AT transition at nucleotide 1618 was found consistently in our sequence. This substitution was not $W$ allele specific, did not alter $\mathrm{Val}^{530}$ encoded at this position, and was assumed to be a strain-specific polymorphism. An AT $\rightarrow$ GC substitution at position 648 was also always found in our sequences resulting in $\mathrm{Glu}^{207}$ being replaced by $\mathrm{Ala}^{207}$ in the c-kit polypeptide. This substitution was also observed in a c-kit brain cDNA clone isolated from BALB/c mice (D. Fowlkes and O. Smithies, pers. comm.).

\section{Discussion}

\section{$c$-kit kinase activity in different $\mathrm{W}$ mutants}

We have shown that the kinase activity associated with the c-kit transmembrane receptor is impaired in physiologic target cell populations derived from mice bearing each of five spontaneous $W$ mutations. As summarized in Table 1, the alleles analyzed confer a wide range of $W$ mutant phenotypes from severe (homozygous lethal) to mild (homozygous viable and fertile). The in vitro coculture assay described here reflected the overall severity of different $W$ phenotypes. Mast cells homozygous for viable alleles $\left(W^{41}, W^{44}, W^{55}, W^{57}\right)$ were found to have a greater capacity to survive on fibroblast feeders than those homozygous for the lethal $W^{37}$ allele. Similarly, the amount of residual c-kit kinase activity in these mast cell cultures correlated with the overall severity of $W$ phenotype. These results support and extend previous observations suggesting that $\mathrm{c}-\mathrm{kit}$ and $W$ are allelic (Chabot et al. 1988; Geissler et al. 1988; Nocka et al. 1989; Bernstein et al. 1990) and provide direct evidence that the tyrosine kinase activity associated with the c-kit protein is a biochemical parameter relevant to c-kit function in those lineages affected by the $W$ locus.

To obtain a more complete understanding of the range of phenotypes conferred by different $W$ alleles, we also analyzed the molecular basis of the deficiencies in c-kit kinase activity. Two broad categories of mutations were revealed. The decreased c-kit kinase activity associated with the mild alleles $W^{44}$ and $W^{57}$ appears to be a consequence of an equivalent decrease in the level of c-kit protein. Rearrangement of the c-kit locus, associated with decreased levels of c-kit mRNA in adult brain, has been reported for the $W^{44}$ allele (Geissler et al. 1988). The data presented here demonstrate that the $W^{44}$ mutation also affects $\mathrm{c}$-kit protein expression in a physiologic target of $W$ mutations. In contrast, no gross rearrangement of the c-kit locus in $W^{57}$ mice was detectable at the level of resolution afforded by Southern blot analysis using cDNA probes (data not shown). Nevertheless, the $W^{57}$ mutation also appears to lower the level of c-kit mRNA in mast cells (data not shown), by affecting either c-kit transcription or mRNA stability.

The other mutant alleles analyzed here were characterized by the expression of normal levels of c-kit proteins with reduced or undetectable in vitro autophosphorylation activity. These results raised the possibility that this class of $W$ alleles arose as a consequence of mutations that directly affect the c-kit tyrosine kinase domain. Consistent with this prediction, DNA sequence analysis revealed the presence of single-point mutations within the kinase domain of $\mathrm{c}-\mathrm{kit}$ isolated from mice bearing each of these mutant alleles. Formal proof that these single amino acid substitutions confer the phenotypes of $W^{37}, W^{41}$, and $W^{55}$ animals awaits the generation of transgenic mice expressing recombinant mutant c-kit proteins. However, the nature and location of these point substitutions, along with the inability to detect additional allele-specific changes in the c-kit-coding sequence, suggest that they are responsible for the defi- 
A
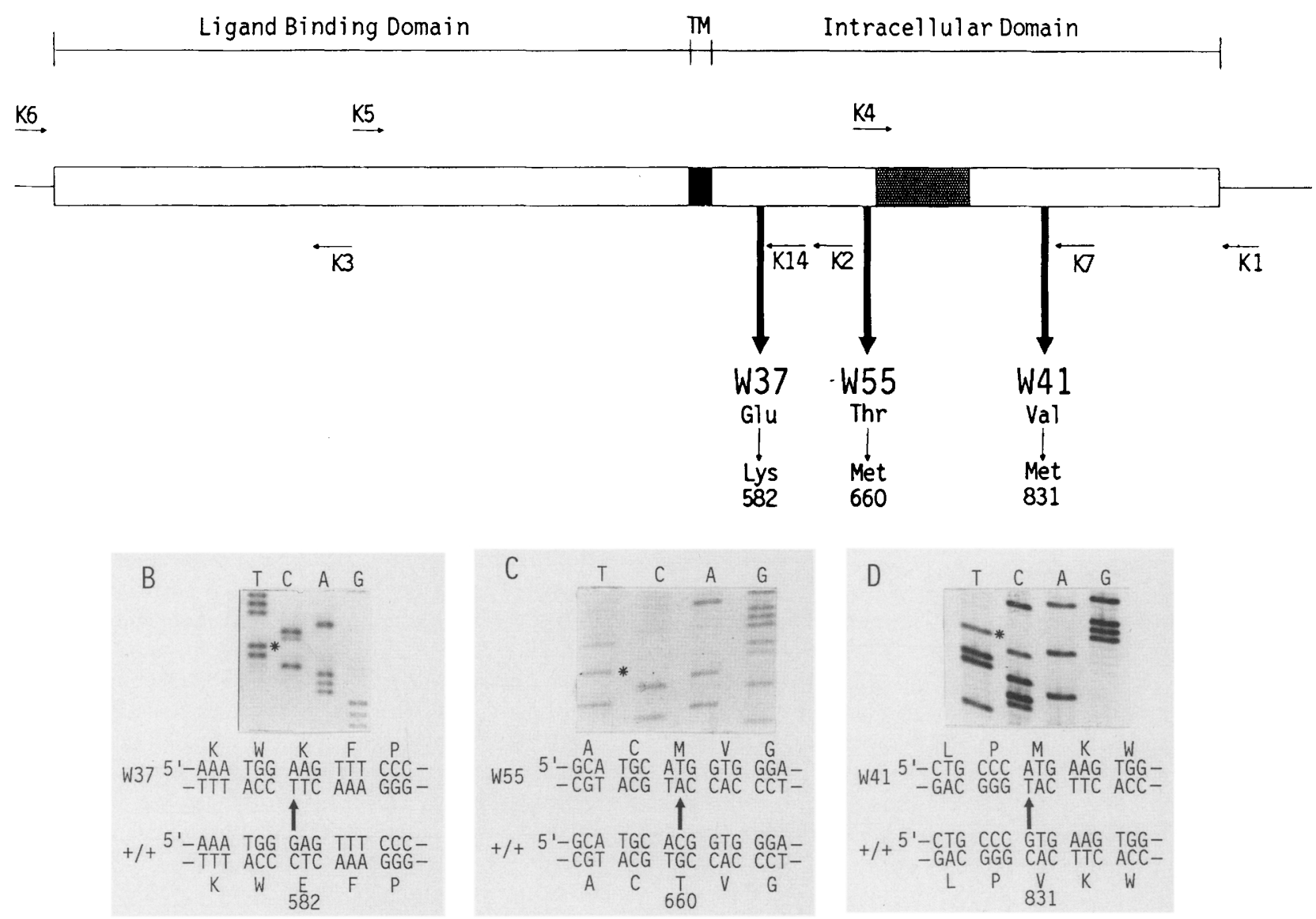

Figure 3. Nucleotide sequence analysis of c-kit cDNA from $W^{37}, W^{55}$, and $W^{41}$ animals. $(A)$ Cloning strategy. The entire coding sequence of c-kit was cloned from total cellular RNA by PCR using the c-kit-specific oligonucleotide pairs K6-K3, K5-K2, and K4-K1 (see Methods). Line indicates noncoding regions of c-kit mRNA; box indicates c-kit-coding sequence; solid area indicates transmembrane domain; shaded area indicates c-kit variable region within the tyrosine kinase domain. Nucleotide sequence determination utilized the series of $\mathrm{c}-k$ it-specific oligonucleotides K1 through K16 (see Methods). (B) GC $\rightarrow$ AT mutation in c-kit cDNA isolated from $W^{37} / W^{37}$ mast cells was detected in $\mathrm{K} 14$ oligonucleotide-primed sequence reactions resulting in substitution of lysine for $\mathrm{Glu}{ }^{582}$. (C) GC $\rightarrow \mathrm{AT}$ point mutation in c-kit from $W^{55} / W^{55}$ mast cells was detected in $\mathrm{K} 4$ oligonucleotide primed sequence reactions resulting in substitution of methionine for $\mathrm{Thr}^{660}$. (D) c-kit cDNA prepared from $W^{41} / W^{41}$ placenta was found to contain a $\mathrm{GC} \rightarrow \mathrm{AT}$ point mutation in $\mathrm{K} 7$ oligonucleotide-primed sequence reactions. This results in $\mathrm{Va} \mathbf{l}^{831}$ being mutated to methionine. $(B$ and $D)$ Lower strand sequence of the relevant regions of representative mutant c-kit cDNA clones; $(C)$ upper strand. $\left({ }^{*}\right)$ Mutated nucleotides. (A) alanine; (C) cysteine, (E) glutamate; $(F)$ phenylalanine; $(G)$ glycine; $(K)$ lysine; $(L)$ leucine; $(M)$ methionine; $(P)$ proline; $(T)$ threonine; (V) valine; (W) tryptophan.

ciencies in hematopoietic, melanocyte, and germ cell lineages of these three $W$ mutants.

All three allele-specific mutations involve $\mathrm{GC} \rightarrow \mathrm{AT}$ transitions (Fig. 3). Spontaneous hydrolytic deamination of 5-methylcytosine to thymine is known to occur at an appreciable frequency in mammalian cells (Wang et al. 1982; Riggs and Jones 1983). Although a specific mismatch repair system has been identified that restores GT mismatches to GC pairs, a small proportion of such mismatches are repaired to mutant AT pairs in mammalian cells (Brown and Jiricny 1987; Wiebauer and Jiricny 1989). Such a mechanism could account for all three mutations detected in the spontaneous $W$ mutants, $W^{37}$, $W^{55}$, and $W^{41}$, as well as the strain-specific polymorphism observed in comparisons of c-kit cDNAs from
C57BL/6 and BALB/c mice. The allele-specific mutations result in point substitutions of amino acids within the kinase domain of c-kit that are highly conserved among the family of protein tyrosine kinases (Fig. 4). Moreover, the nature of these amino acid substitutions is consistent with the observed phenotypes induced by each $W$ allele; the moderately dominant, homozygous viable alleles $W^{55}$ and $W^{41}$, contain more conservative substitutions than that detected in the homozygous lethal allele, $W^{37}$.

\section{Lethal allele $\mathrm{W}^{37}$}

The amino acid residue $\mathrm{Glu}^{582}$, replaced by lysine in c-kit from $W^{37}$ mice, lies amino terminal to the ATPbinding consensus sequence G-X-G-X-X-G found in all 
A.

\begin{tabular}{|c|c|c|c|c|c|c|c|c|c|c|c|c|c|c|c|c|c|}
\hline & 578 & & & & & & & & & & & & & & & & \\
\hline c-kit $\mathrm{w}^{37}$ & - & - & K & -- & -1 & & & & & & & - & & & & - & \\
\hline -kit & D H & K V & $\mathrm{E}$ & $F \quad P$ & $\mathrm{R} \mathrm{N}$ & $\mathrm{R}$ & L S & $\mathrm{F}$ & G & $\mathrm{K}$ & $\mathrm{T}$ & L G & A & G & A & $F G$ & $\mathrm{~K}$ \\
\hline$c-f m s$ & $\mathrm{~N} E$ & - & - & -- & & $\mathrm{N}$ & $-Q$ & - & 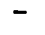 & & 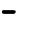 & -4 & & 7 & - & - & - \\
\hline PDGFR & $-S$ & $T$ & - & L - & $-D$ & $Q$ & $-v$ & L & - & $\mathrm{R}$ & - & & $\mathrm{S}$ & $=$ & - & & Q \\
\hline ET & $-P$ & - & - & - & $-k$ & $\mathrm{~N}$ & $-v$ & L & - & - & - & - & $\mathrm{E}$ & $=$ & $\mathrm{E}$ & -7 & - \\
\hline INS.R & $P D$ & E & - & V S & $-E$ & $\mathbf{K}$ & I $\mathrm{T}$ & L & L & $\mathrm{R}$ & E & - & $Q$ & & $\mathbf{S}$ & - & $M$ \\
\hline IGFIR & $P D$ & E & - & V A & $-E$ & $\mathrm{~K}$ & I $\mathrm{T}$ & $M$ & $S$ & $\mathrm{R}$ & E & - & $Q$ & & $S$ & - & $M$ \\
\hline ILR & $P \quad D$ & D & - & V L & $-E$ & $\mathbf{N}$ & I I & $Q$ & $\mathrm{~L}$ & A & P & -7 & Q & $=$ & S & - & M \\
\hline EGFR & A L & L $\mathrm{F}$ & R I & L K & E T & $\mathrm{E}$ & $F \quad \mathrm{~K}$ & $\mathrm{~K}$ & I & - & V & & $S$ & 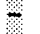 & - & - & $T$ \\
\hline NEU & A $Q$ & M I & I & L K & E T & $\mathrm{E}$ & $-R$ & $\mathrm{~K}$ & $\mathrm{~V}$ & - & V & - & S & 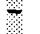 & - & - & $\mathrm{T}$ \\
\hline DER & $C \mathrm{~K}$ & L $\mathrm{F}$ & R & V K & D A & $\mathbf{E}$ & $-R$ & $\mathrm{~K}$ & - & & V & & $\mathbf{M}$ & & & & $\mathrm{R}$ \\
\hline -src & K D & A & - & $I-$ & & $\mathbf{S}$ & $-R$ & L & $E$ & $\mathrm{~V}$ & K & & $Q$ & & C & - & E \\
\hline Dsrc28 & H D & $\mathrm{K}$ & - & I $\mathrm{H}$ & P I & $\mathbf{Q}$ & $-M$ & & & $\mathrm{E}$ & $E$ & & $\mathbf{S}$ & & & & \\
\hline$-a b$ & Y D & - & - & M E & $-T$ & D & I $\mathrm{T}$ & $M$ & 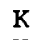 & $\mathrm{H}$ & K & & G & . & Q & $Y$ & E \\
\hline$a b l$ & $P \quad D$ & E & - & L $\quad$ D & $-s$ & $\mathbf{E}$ & I I & $M$ & & $N$ & & - & & & & $Y$ & $D$ \\
\hline
\end{tabular}

B.

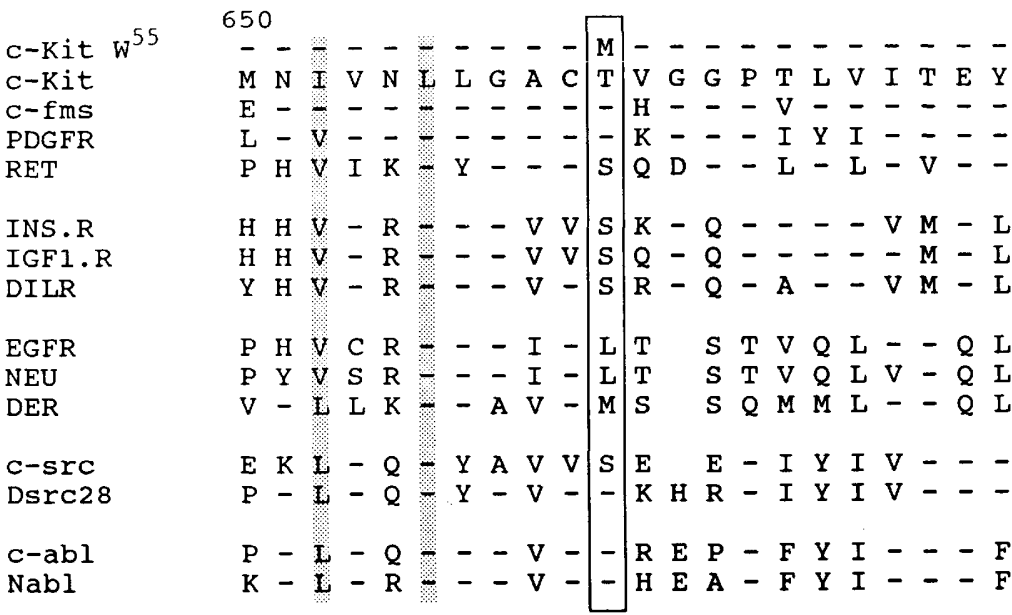

c.

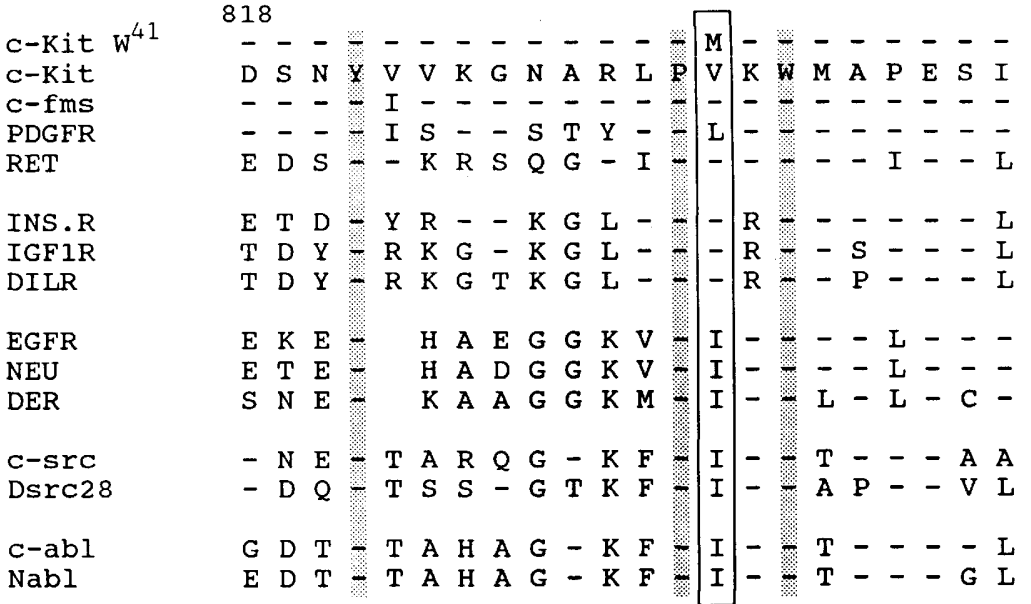

Figure 4. c-kit residues mutated in $W^{37}$, $W^{55}$, and $W^{41}$ animals are highly conserved in protein tyrosine kinases. Amino acid residues $578-602(A), 650-670(B)$, and 818-839 $(C)$ of murine c-kit (Qui et al. 1988) are compared with homologous regions of other protein tyrosine kinases representing PDGF receptor, insulin receptor and EGF receptor subfamilies of transmembrane receptor tyrosine kinases, $s r c$ and $a b l$ subfamilies of cytoplasmic tyrosine kinases, and c-kit isolated from animals bearing mutant alleles $W^{37}, W^{55}$, and $W^{41}$, respectively. Conserved residues mutated in each $W$ allele are shown in open boxes. Shaded boxes in $A$ indicate the invariant glycine residues of the ATPbinding domain within conserved subdomain $\mathrm{I}$; in $B$, conserved residues within subdomain IV; and in $C$, invariant residues within conserved subdomain VIII of protein tyrosine kinases (Hanks et al. 1988), as well as the major autophosphorylation site ( $\mathrm{Tyr}^{821}$ in c-kit) of many tyrosine kinases. (c-fms) Human c-fms (Coussens et al. 1986); (PDGFR) human platelet-derived growth factor receptor (Yarden et al. 1986); (RET) human ret proto-oncogene (Takahashi and Cooper 1987); (INS.R) human insulin receptor (Ullrich et al. 1985); (IGF1.R) human insulin-like growth factor I receptor (Ullrich et al. 1986); (DILR) Drosophila insulinlike receptor (Nishida et al. 1986); (EGFR) human epidermal growth factor receptor (Ullrich et al. 1984); (NEU) human c-neu (Yamamoto et al. 1986); (DER) Drosophila EGF receptor (Livneh et al. 1985); (c-src) human c-src (Anderson et al. 1985); (Dsrc28) Drosophila src (Gregory et al. 1987); (c-abl) human c-abl (Shtivelman et al. 1986); (Nabl) Caenorhabiditis elegans abl (Goddard et al. 1986). (A) alanine; (C) cysteine; (D) aspartate; (E) glutamate; $(F)$ phenylalanine; $(\mathrm{G})$ glycine; $(\mathrm{H})$ histidine; (I) isoleucine; (K) lysine; (L) leucine; (M) methionine; (N) asparagine; (P) proline; (Q) glutamine; (R) arginine; (S) serine; (T) threonine; (V) valine; (W) tryptophan; (Y) tyrosine. Dashes indicate residues identical to those in c-kit. Gaps were introduced into conserved subdomains IV and VIII of EGFR subfamily for optimal alignment. Sequences were aligned by eye. protein kinases, a subdomain known to be critical for kinase activity (Kamps et al. 1984; Weinmaster et al. 1986; Chou et al. 1987; Odawara et al. 1989; for review, see Yarden and Ullrich 1988). $\mathrm{Glu}^{582}$ forms part of the consensus sequence W-E-X-X-R, found not only in all known members of the platelet-derived growth factor (PDGF) subfamily but also in proteins of the insulin receptor subfamily of transmembrane tyrosine kinases and some, but not all, members of c-src and c-abl subfamilies (Fig. 4A). Strikingly, this consensus sequence is not 
found in members of the EGF receptor (EGFR) subfamily of transmembrane receptor tyrosine kinases but is replaced by another conserved sequence R-I-L/V-K-E/D (Fig. 4A). Deletion analysis of v-fps has established that, although this region is not essential for catalytic function, its inclusion greatly stimulates kinase activity ( $\mathrm{Sa}$ dowski and Pawson 1987). The definition of a point mutation in this region that results in markedly decreased in vitro autophosphorylation activity is consistent with a positive function for this domain and identifies $\mathrm{Glu}^{582}$ as a residue critical for this activity.

A change in the relative abundance of the 160- and $124-\mathrm{kD}$ forms of $\mathrm{c}-\mathrm{kit}$ was also associated with the $W^{37}$ mutation. Point mutations within the extracellular domains of c-fms and the insulin receptor have been shown to affect processing of receptor tyrosine kinases (Roussel et al. 1988; Woolford et al. 1988; Accili et al. 1989). However, no allele-specific amino acid substitutions were detected in the extracellular domain of c-kit cloned from cells homozygous for the $W^{37}$ mutation /data not shown). It is possible that the glutamic acid to lysine mutation detected in $W^{37}$ c-kit alters the conformation of the protein in such a way as to impair processing or destabilize the $160-\mathrm{kD}$ form of $\mathrm{c}-\mathrm{kit}$. However, because neither form was found to have autophosphorylation activity, it is likely that the primary phenotypic consequences of this mutation arise from the loss of kinase activity.

\section{Moderate alleles $\mathrm{W}^{55}$ and $\mathrm{W}^{41}$}

Thr ${ }^{660}$, mutated to methionine in c-kit from animals bearing the $W^{55}$ allele, lies within conserved subdomain IV of protein tyrosine kinases, within the ATP-binding domain (Fig. 4B; Hanks et al. 1988). This residue is conserved as either threonine or serine not only in other members of the PDGF receptor and insulin receptor subfamilies of transmembrane protein tyrosine kinases but also in some proteins of the $s r c$ and $a b l$ subfamilies of cytoplasmic tyrosine kinases (Fig. 4B). Like the $W^{37}$ allele, the mutated residue in $W^{55}$ is not conserved within the EGF receptor subfamily. To date, a putative role for this subdomain in tyrosine kinase catalytic activity has been deduced solely from sequence comparisons (Hanks et al. 1988). The data presented here indicate that substitution of $\mathrm{Thr}{ }^{660}$ by methionine directly affects $\mathrm{c}-k i t$ kinase activity. Conservation of residues with aliphatic hydroxyl side chains at this position may reflect constraints necessary to retain suitable secondary structure of the ATP-binding domain.

c-kit residue $\mathrm{Val}^{831}$, mutated to methionine in $W^{41}$ animals, lies within conserved subdomain VIII of protein kinases (Fig. 4C; Hanks et al. 1988). The strong evolutionary conservation of this subdomain and its proximity to the major autophosphorylation site of many tyrosine kinases suggests that this region is critical for catalytic activity, a hypothesis confirmed by mutational analyses (for review, see Yarden and Ullrich 1988). However, within this subdomain, $\mathrm{Val}^{831}$ is part of a sequence conserved across tyrosine kinases but not serine/ threonine kinases, indicating that this residue may be important for recognition of the correct hydroxyamino acid.

An independence of pleiotropic effects of mutations at the $W$ locus is seen in $W^{41}$ homozygotes which, unlike $W^{55} / W^{55}$ animals, retain normal fertility (Table 1 ). There are several possible explanations for this phenotype. The c-kit signal transduction pathway may involve substrates in germ cells that are different from those in hematopoietic stem cells or melanoblasts. Tyrosine phosphorylation of such substrates may be differentially affected by the $\mathrm{Va}^{183}$ to $\mathrm{Met}^{831}$ mutation. Alternatively, the residual level of c-kit kinase activity present in $W^{41}$ animals may be sufficient for normal germ cell development but inadequate for normal melanogenesis or hematopoiesis, or the germ cell migration pathway may provide larger amounts of $\mathrm{c}-\mathrm{kit}$ ligand than those for melanocyte and hematopoietic stem cell migrations.

\section{Dominant-negative $\mathrm{W}$ phenotypes}

$W$ alleles have all been identified initially by their ability to confer a dominant phenotype on the melanocyte lineage. In some, but not all, $W$ mutants, dominant phenotypes are also apparent in the hematopoietic and germ cell lineages (Table 1). Both the data presented here and that reported previously (Chabot et al. 1988; Geissler et al. 1988; Nocka et al. 1989; Bernstein et al. $1990)$ indicate that dominant $W$ phenotypes arise as a consequence of a loss of $c-k i t$ kinase function. Our data demonstrate that such dominant phenotypes can arise by one of two classes of mutation: those that affect c-kit expression levels and those that result in expression of a defective protein as a consequence of point substitutions within highly conserved residues in the c-kit polypeptide. Mutations that confer reduced levels of an apparently normal protein give mild heterozygous phenotypes $\left(W^{44}\right)+$ or $W^{57} \mid+$; Table 1$)$, whereas point substitutions in c-kit give more strongly dominant heterozygous phe-

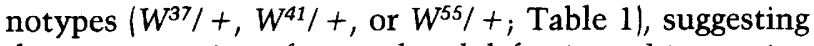
that coexpression of normal and defective $\mathrm{c}$-kit proteins in the same cell inhibits proper signal transduction by the wild-type protein. There are precedents for mutations in transmembrane receptor tyrosine kinases inducing such dominant-negative phenotypes. Truncated forms of EGFR have been shown to act in a dominantnegative manner in in vitro cell lines (Basu et al. 1989). Deletion of the kinase domain of the insulin receptor results in autosomal dominant inheritance of insulin resistance in humans (Kadowaki et al. 1988; Taira et al. 1989), and a point mutation in the ligand-binding domain of the human insulin receptor confers decreased insulin binding in cell culture and insulin resistance in heterozygote individuals (Klinkhamer et al. 1989).

The occurrence of such dominant-negative phenotypes is presumably a consequence of the mechanism by which this class of proteins transduces extracellular signals. The regulation and activation of transmembrane 
receptor tyrosine kinases appears to be controlled by a dynamic equilibrium between monomeric and aggregated forms of receptors (for review, see Carpenter 1987). Ligand-dependent activation of nonaggregated forms of EGFR has been reported (Biswas et al. 1985; Basu et al. 1986; Koland and Cervione 1988; Northwood and Davis 19881, but the activity of aggregated forms of transmembrane protein tyrosine kinases is unclear. There is some data to suggest that binding of ligand to EGFR pushes the dynamic equilibrium in favor of aggregates, thus activating kinase activity (Böni-Schnetzler and Pilch 1987; Yarden and Schlessinger 1987); and it has been shown that the oncogenic form of neu exists preferentially on the cell surface in the aggregated form (Drebin et al. 1985; Weiner et al. 1989). In such a model, the point mutations described here for $W^{37}, W^{55}$, and $W^{41}$ could act in a dominant-negative manner by producing defective heterodimers with impaired kinase activity or nonfunctional monomers that bind ligand nonproductively in situations where ligand is limiting. An alternative model suggests that aggregation of receptors results in negative regulation, with ligand binding acting as a positive regulator by pushing the dynamic equilibrium in favor of active monomers possibly stabilized by nucleotide binding (Basu et al. 1986; Koland and Cervione 1988; Northwood and Davis 1988). In this case, the point mutations may confer an inherent instability in monomers even in the presence of ligand, thus pushing the equilibrium in favor of inactive dimers. The mutations could also produce defective heterodimers insensitive to ligand-mediated activation.

\section{Transmembrane receptor tyrosine kinases and mammalian development}

The functional definition of amino acid residues and domains critical for protein tyrosine kinase function has been largely restricted to analyses of mutations that activate the kinase domain, as determined by their ability to transform cells in vitro or cause tumors in transgenic mice. These mutations all constitute gain-of-function alterations and thus represent only a subset of possible alterations in this developmentally important class of molecules. The data presented here provide the first examples of the consequences of single amino acid substitutions in a transmembrane tyrosine kinase gene on mammalian development. A large number of spontaneous and mutagen-induced alleles at the W/c-kit locus are available (Green 1981). The molecular characterization of additional $W$ mutations will greatly facilitate the definition of the structural elements necessary for signal transduction by transmembrane protein tyrosine kinases in vivo and also provide further insight into the roles played by c-kit in mammalian embryogenesis and cellular differentiation. The mutations defined here all mapped to amino acids highly conserved among the family of protein tyrosine kinases. It will be of considerable interest to determine whether the introduction of analogous germ line mutations in other members of the receptor tyrosine kinase gene family also results in dominant-negative developmental defects in the mouse.

\section{Methods}

Animals

Normal $+1+$ mice and the $W$ mutants $W^{v} /+, W^{37} /+, W^{41} /+$, $W^{44} /+, W^{55} /+$, and $W^{57 /}+$, all on a C57BL/6 background, and $\mathrm{WB} / \mathrm{Re} W /+$ mice were purchased from Jackson Laboratory (Maine). New Zealand rabbits were obtained from the Animal Division, Mt. Sinai Hospital Research Institute. Mouse embryos were obtained by natural matings (normal light cycle), fertilization being assumed to occur at midnight prior to detecting vaginal plugs. The developmental age of dissected embryos was assessed in accordance with Theiler (1972). Fetuses homozygous for lethal $W$ alleles were distinguished from heterozygous litter mates by their anemic appearance and verified by their inability to form CFU-S in irradiated syngeneic hosts and their deficiency in CFU-E.

\section{Cell culture}

Single cell suspensions of adult bone marrow or 15.5-day postcoitum fetal liver were prepared in Iscove's modified Dulbecco's medium (IMDM), seeded at $5 \times 10^{5}$ cells $/ \mathrm{ml}$ in IMDM containing $5 \%$ fetal calf serum (FCS) supplemented with $10 \%$ WEHI-3-conditioned medium, and grown at $37^{\circ} \mathrm{C}$ in an incubator gassed with $5 \% \mathrm{CO}_{2}$ at a relative humidity $100 \%$. After 6 days, cells were pelleted and resuspended in $1 \mathrm{ml}$ of the original culture medium supplemented with $4 \mathrm{ml}$ of mast cell mix [IMDM, $0.05 \%$ BSA, 1\% FCS, $2 \mu \mathrm{g} / \mathrm{ml}$ concanavalin A, $5 \mu \mathrm{g} / \mathrm{ml}$ transferrin, $5 \mu \mathrm{g} / \mathrm{ml}$ insulin, $0.5 \mathrm{U} / \mathrm{ml}$ murine IL-3 from the myeloma cell line X63Ag8-653 carrying a recombinant IL-3 cDNA expression vector (Karasuyama and Melchers 1988)]. Every 3 days, $80 \%$ of the medium was changed until cells achieved a concentration $>1.5 \times 10^{6}$ cells $/ \mathrm{ml}$, at which point cells were maintained at $4 \times 10^{5}$ to $5 \times 10^{5}$ cells $/ \mathrm{ml}$ in mast cell mix. Mature mast cell populations were generated after 5-6 weeks of culture.

For coculture experiments, $5 \times 10^{5}$ mast cells were seeded onto confluent monolayers of normal mouse embryo fibroblasts (Fujita et al. 1989) in IMDM containing 5\% FCS. Medium was changed every 4 days. Mast cells were identified by staining a cytocentrifuge preparation of trypsinized cultures with Alcian Blue.

For metabolic labeling, $5 \times 10^{6}$ mast cells were washed twice in prewarmed Tris-saline and incubated for $4 \mathrm{hr}$ at $37^{\circ} \mathrm{C}$ in 2 $\mathrm{ml}$ of DMEM lacking methionine (Flow Laboratories), supplemented with $5 \%$ FCS (Flow), 10\% WEHI-conditioned medium and $200 \mu \mathrm{Ci}\left[{ }^{35} \mathrm{~S}\right.$ ]methionine (Amersham).

\section{Nucleic acids}

pTrpE-kit contains a 928-bp PvuII-PvuII restriction fragment of a $3.7-\mathrm{kb}$ murine $\mathrm{c}-\mathrm{kit}$ cDNA clone ligated in frame into the TrpE fusion vector pATH2 (Crivellone et al. 1988). Total cellular RNA was prepared by the guanidinium isothiocyanate method (Chirgwin et al. 1979). Mouse c-kit-specific oligonucleotides were purchased from the Banting Research Institute (Toronto) and correspond to the following nucleotides in the published murine c-kit cDNA sequence (Qui et al. 1988): K1: 2967-2988; K2: 1959-1980; K3: 1066-1087; K4: 1981-2002; K5: 1088-1109; K6: -7-15; K7: 2611-2632; K8: 1734-1755; K9: 413-429; K10: 601-617; K11: 811-827; K12: 1401-1417; K13: 1607-1623; K14: 1804-1820; K15: 2415-2431; K16: 2801-2817. 


\section{c-kit-specific antisera}

Twenty milliliters of M9 medium, supplemented with $0.5 \%$ (wt/vol) casamino acids, $10 \mu \mathrm{g} / \mathrm{ml}$ thiamine, $20 \mu \mathrm{g} / \mathrm{ml}$ tryptophan, and $50 \mu \mathrm{g} / \mathrm{ml}$ of ampicillin, was inoculated with a single ampicillin-resistant Escherichia coli colony bearing the plasmid pTrpE-kit. Following overnight incubation at $37^{\circ} \mathrm{C}$, the culture was added to $200 \mathrm{ml}$ prewarmed M9 medium supplemented as described above but with the omission of tryptophan. After a 3 -hr incubation at $37^{\circ} \mathrm{C}$, culture medium was supplemented with indole acrylic acid (Sigma) to a final concentration of $5 \mu \mathrm{g} / \mathrm{ml}$ and incubated at $37^{\circ} \mathrm{C}$ with vigorous aeration for an additional $2 \mathrm{hr}$. Cells were harvested by centrifugation, resuspended in $5 \mathrm{ml}$ of cracking buffer [0.01 $\mathrm{M}$ sodium phosphate ( $\mathrm{pH} 7.2), 1 \% 2$-mercaptoethanol, $1 \%$ SDS, $6 \mathrm{M}$ urea] and incubated at $37^{\circ} \mathrm{C}$ for $1 \mathrm{hr}$ prior to preparative SDS-PAGE. The TrpE-kit fusion protein $(74-\mathrm{kD})$ was excised from the preparative gel, electroeluted, and concentrated with polyethyleneglycol to a final concentration of $1.5 \mathrm{mg} / \mathrm{ml}$.

For immunization, rabbits were injected with $150 \mu \mathrm{g}$ of TrpE-kit fusion protein in $500 \mu \mathrm{l}$ of Freund's complete adjuvant (Difco) and boosted with $50 \mu \mathrm{g}$ of fusion protein in Freund's incomplete adjuvant. Antisera reactivity was tested by Western blot of TrpE-kit-induced protein.

\section{Immunoprecipitation analyses}

Cells were washed twice with ice-cold Tris-saline and lysed in $1 \mathrm{ml}$ of RIPA buffer [50 mM Tris- $\mathrm{HCl}(\mathrm{pH} 7.5), 150 \mathrm{mM} \mathrm{NaCl}$, $1 \%$ (vol/vol) Triton-X-100,1\% (wt/vol) sodium deoxycholate, $0.1 \%$ (wt/vol) SDS, $100 \mu \mathrm{M}$ sodium vanadate, $100 \mu \mathrm{g} / \mathrm{ml}$ leupeptin, $1 \mathrm{~mm}$ phenylmethylsulfonylfluoride]. Lysates were precleared by centrifugation for $45 \mathrm{~min}$ at $4^{\circ} \mathrm{C}$ and incubation of $500 \mu \mathrm{l}$ of supernatant for $2 \mathrm{hr}$ at $4^{\circ} \mathrm{C}$ with $50 \mu \mathrm{l}$ rabbit preimmune serum plus $50 \mu \mathrm{l}$ washed $10 \%$ (wt/vol) Staphylococcus aureus cells (Calbiochem). Equivalent TCA-precipitable counts of lysates were then incubated with $50 \mu \mathrm{l}$ rabbit pre-immune or c-kit antisera and $50 \mu \mathrm{l}$ of $10 \%$ protein-A/Sepharose (Pharmacial for $2 \mathrm{hr}$ at $4^{\circ} \mathrm{C}$. Immunoprecipitates were washed three times in $500 \mu$ lice-cold RIPA buffer, two times in ice-cold 50 mM Tris- $\mathrm{HCl}(\mathrm{pH} 7.5)$, resuspended in $50 \mu \mathrm{l} 1 \times \mathrm{SDS}$ sample buffer [ $10 \%$ (vol/vol) glycerol, $5 \%$ (vol/vol) 2-mercaptoethanol, $2.3 \%$ (wt/vol) SDS, $0.0625 \mathrm{M}$ Tris- $\mathrm{HCl}$ at $\mathrm{pH} 6.8,0.002 \%$ (wt/ vol) bromophenol blue] and subjected to $7.5 \%$ SDS-PAGE. Gels were fixed with $10 \%$ acetic acid and $30 \%$ methanol and treated with Enhance (DuPont) prior to autoradiography.

\section{In vitro kinase assays}

Following immunoprecipitation, immune complexes were washed twice in ice-cold RIPA buffer, twice in ice-cold $50 \mathrm{~mm}$ Tris- $\mathrm{HCl}(\mathrm{pH} 7.5)$, and $1 \%(\mathrm{vol} / \mathrm{vol})$ Triton X-100 and resuspended in $10 \mu \mathrm{l}$ kinase reaction buffer $[10 \mathrm{mM} \mathrm{MnCl}, 1 \%$ (vol/ vol) Triton X-100, $10 \mu \mathrm{Ci}\left[\gamma^{-32} \mathrm{P}\right] \mathrm{ATP}(3000 \mathrm{Ci} / \mathrm{mmole}$, Amersham)]. Following incubation for $10 \mathrm{~min}$ at $30^{\circ} \mathrm{C}$, an equal volume of $2 \times$ SDS sample buffer was added, and samples were subjected to $7.5 \%$ SDS-PAGE. Following electrophoresis, gels were fixed with $10 \%$ acetic acid and $30 \%$ methanol and treated with $1 \mathrm{M}$ potassium hydroxide (Cooper et al. 1983) prior to autoradiography.

\section{cDNA cloning}

Total cellular RNA $(20 \mu \mathrm{g})$ was mixed with $50 \mathrm{ng}$ of each $\mathrm{K} 1$, $\mathrm{K} 2$, and $\mathrm{K} 3 \mathrm{c}-\mathrm{kit}$-specific oligonucleotides in $0.2 \mathrm{M}$ sodium chloride, $20 \mathrm{mM}$ PIPES (pH 6.5), and $0.5 \mathrm{mM}$ EDTA in a final volume of $20 \mu \mathrm{l}$, denatured at $65^{\circ} \mathrm{C}$ for $2 \mathrm{~min}$, and annealed by incubation at $42^{\circ} \mathrm{C}$ for $3 \mathrm{hr}$. First-strand cDNA was then generated by incubation of the above mix in $50 \mathrm{~mm}$ Tris- $\mathrm{HCl}(\mathrm{pH} 8.3), 10 \mathrm{~mm}$ $\mathrm{MgCl}_{2}, 20 \mathrm{mM} \mathrm{Na}_{2} \mathrm{PO}_{4}, 40 \mathrm{~mm} \mathrm{KCl}, 2 \mathrm{~mm}$ DTT, $0.4 \mathrm{~mm}$ each of dCTP, dGTP, dATP, and dTTP, 40 units RNasin (Promega Biotec), 20 units AMV reverse transcriptase (Boehringer-Mannheim), and 10 units M-MuLV reverse transcriptase (Pharmacia) in a final volume of $50 \mu \mathrm{l}$ and incubated at $42^{\circ} \mathrm{C}$ for $2 \mathrm{hr}$.

Ten percent of the above reaction mix was then denatured in $0.4 \mathrm{M} \mathrm{NaOH}$ for $10 \mathrm{~min}$ at $50^{\circ} \mathrm{C}$, neutralized by the addition of hydrochloric acid, and PCR was carried out by incubation in $1 \times$ TaqI buffer $[50 \mathrm{mM} \mathrm{KCl}, 10 \mathrm{mM}$ Tris- $\mathrm{HCl}\langle\mathrm{pH} 8.3\}, 1.5 \mathrm{mM}$ $\mathrm{MgCl}_{2}, 0.01 \%$ gelatin], $0.2 \mu \mathrm{M}$ dCTP, dGTP, dATP, and dTTP, $0.2 \mathrm{mg} / \mathrm{ml}$ gelatin, $500 \mathrm{ng}$ of each of c-kit-specific oligonucleotide pairs $\mathrm{K} 1-\mathrm{K} 4, \mathrm{~K} 2-\mathrm{K} 5$, or $\mathrm{K} 3-\mathrm{K} 6$, as appropriate, and 2.5 units TaqI polymerase (Cetus) in a final volume of $100 \mu 1$. The reaction mix was subjected to incubation at $93^{\circ} \mathrm{C}$ for $90 \mathrm{sec}$, $55^{\circ} \mathrm{C}$ for $2 \mathrm{~min}$, and $72^{\circ} \mathrm{C}$ for $3 \mathrm{~min}$ for a total of 25 cycles in an Ericomp twin block variable temperature cycler. PCR products were electrophoresed in $0.8 \%$ agarose gel. cDNA fragments of the appropriate size were excised, eluted, blunted with T4 DNA polymerase (Boehringer-Mannheim), and ligated with HincIIlinearized pKS plasmid vector (Stratagene) at $4^{\circ} \mathrm{C}$ for $12-16 \mathrm{hr}$. The ligation mix was transformed into $E$. coli $\mathrm{DH} 5 \alpha \mathrm{F}^{\prime}$ and recombinant clones were detected by blue/white color selection on ampicillin plates supplemented with $0.5 \mathrm{mM}$ IPTG and 100 $\mu \mathrm{g} / \mathrm{ml} \mathrm{X-gal.}$

\section{Nucleotide sequence analysis}

Double-stranded plasmid DNA was prepared for DNA sequence determination as described previously (Hattori and Sakaki 1986). DNA sequence reactions were performed using the modified T7 DNA polymerase Sequenase (U.S. Biochemicals) essentially in accordance with the conditions recommended by the manufacturer.

\section{Autoradiography}

Detection of ${ }^{35} \mathrm{~S}$-radiolabeled proteins and nucleic acids was carried out using Kodak XAR-5 or Fuji X-ray film, respectively, at room temperature. Detection of ${ }^{32} \mathrm{P}$-radiolabeled proteins was performed using Kodak XAR-5 film with intensifying screens at $-70^{\circ} \mathrm{C}$.

\section{Acknowledgments}

We thank Tony Pawson and members of his laboratory for helpful suggestions and discussions during the course of this work. We are grateful to Barbara Peacock-Phillips for maintenance of mouse stocks, Peter Besmer for providing a c-kit cDNA clone, Jun Fujita and Fritz Melchers for gifts of cell lines, Norman Iscove and Jamie Dunn for technical advice, Jane Barker, Dana Fowlkes, and Oliver Smithies for access to unpublished data, and Patrice Dubreuil for useful discussion. Karen Babchuck's assistance in some of the DNA sequencing is gratefully acknowledged. A.D.R. acknowledges receipt of a NATO postdoctoral fellowship. L.F. is a recipent of an EMBO long-term postdoctoral fellowship. R.R. is a Medical Research Council of Canada Fellow. This work is supported by grants from the Medical Research Council of Canada, the National Cancer Institute of Canada, and the National Institutes of Health.

\section{References}

Accili, D., C. Frapier, L. Mosthaf, C. McKeon, S.C. Elbein, M.A. Permutt, E. Ramos, E. Lander, A. Ullrich, and S. Taylor. 
1989. A mutation in the insulin receptor gene that impairs transport of the receptor to the plasma membrane and causes insulin-resistant diabetes. EMBO J. 8: 2509-2517.

Anderson, S.K., C.P. Gibbs, A. Tanaka, H.-J. Kung, and D.J. Fujita. 1985. Human cellular src gene: Nucleotide sequence and derived amino acid sequence of the region coding for the carboxy-terminal two-thirds of pp60 ${ }^{\text {c-src }}$. Mol. Cell. Biol. 5: $1122-1129$.

André, C., L. d'Auriol, C. Lacombe, S. Gisselbrecht, F. Galibert. 1989. c-kit mRNA expression in human and murine hematopoietic cell lines. Oncogene 4: 1047-1049.

Baker, N.E. and G.M. Rubin. 1989. Effect on eye development of dominant mutations in Drosophila homologue of the EGF receptor. Nature 340: 150--153.

Basu, M., A. Sen-Majumdar, A. Basu, U. Murthy, and M. Das. 1986. Regulation of kinase and intermolecular bonding in intact and truncated epidermal growth factor receptor. $I$. Biol. Chem. 261: 12879-12882.

Basu, A., M. Raghunath, S. Bishayee, and M. Das. 1989. Inhibition of tyrosine kinase activity of the epidermal growth factor (EGF) receptor by a truncated form that binds to EGF: Role for receptor interreceptor interaction in kinase regulation. Mol. Cell Biol. 9: 671-677.

Bernstein, A., B. Chabot, P. Dubreuil, A.D. Reith, K. Nocka, S. Majumder, P. Ray, and P. Besmer. 1990. The mouse W/c-kit locus. In Molecular control of haemopoiesis. CIBA Found. Symp. vol. 148, pp. 158-172. Wiley, Chichester.

Biswas, R., M. Basu, A. Sen-Majumdar, M. Das. 1985. Intrapeptide autophosphorylation of the EGF-receptor: Regulation of kinase catalytic function by receptor dimerization. Biochemistry 24: 3795-3802.

Böni-Schnetzler, M. and P.F. Pilch. 1987. Mechanism of epidermal growth factor receptor autophosphorylation and high-affinity binding. Proc. Nat1. Acad. Sci. 84: 7832-7836.

Brown, T.C. and J. Jiricny. 1987. A specific mismatch repair event protects mammalian cells from loss of 5-methylcytosine. Cell 50: 945-950.

Carpenter, G. 1987. Receptors for epidermal growth factor and other polypeptide mitogens. Ann. Rev. Biochem. 56: 881914.

Chabot, B., D.A. Stephenson, V.M. Chapman, P. Besmer, and A. Bernstein. 1988. The proto-oncogene c-kit encoding a transmembrane tyrosine kinase receptor maps to the mouse $W$ locus. Nature 335: 88-89.

Chirgwin, J.M., A.E. Przybyla, R.J. MacDonald, and W.J. Rutter. 1979. Isolation of biologically active ribonucleic acid from sources enriched in ribonuclease. Biochemistry 18: 52945299.

Chou, C.K., T.J. Dull, D.S. Russell, R. Gherzi, D. Lebwohl, A. Ullirich, and O.M. Rosen. 1987. Human insulin receptors mutated at the ATP-binding site lack protein tyrosine kinase acitivity and fail to mediate postreceptor effects of insulin. J. Biol. Chem. 262: 1842-1847.

Cooper, J.A., B.M. Sefton, and T. Hunter. 1983. Detection and quantification of phosphotyrosine in proteins. Methods Enzymol. 99: 387-402.

Coussens, L., C. Van Beveren, D. Smith, E. Chen, R.L. Mitchell, C.M. Isacke, I.M. Verma, and A. Ullrich. 1986. Structural alteration of viral homologue of receptor protooncogene fms at carboxyl terminus. Nature 320: 277-280.

Crivellone, M.D., M. Wu, and A. Tzagoloff. 1988. Assembly of the mitochondrial membrane system. I. Biol. Chem. 263: $14323-14333$.

Drebin, J.A., V.C. Link, D.F. Stern, R.A. Weinberg, and M.I. Greene. 1985. Downmodulation of an oncogene protein product and reversion of the transformed phenotype by monoclonal antibodies. Cell 41: 695-706.

Fujita, J., H. Nakayama, H. Onoue, Y. Ebi, Y. Kanakura, A. Kuriu, and Y. Kitamura. 1988a. Failure of $W / W^{v}$ mouse-derived cultured mast cells to enter $S$ phase upon contact with NIH3T3 fibroblasts. Blood 72: 463-468.

Fujita, J., H. Nakayama, H. Onoue, Y. Kanakura, T. Nakano, H. Asai, S. Takeda, T. Honjo, and Y. Kitamura. 1988b. Fibroblast-dependent growth of mouse mast cells in vitro: Duplication of mast cell depletion in mutant mice of $W / W^{v}$ genotype. I. Cell. Physiol. 134: 78-84.

Fujita, J., H. Onoue, Y. Ebi, H. Nakayama, and Y. Kanakura, Y. 1989. In vitro duplication and in vivo cure of mast-cell deficiency of $S 1 / S 1^{d}$ mutant mice by cloned 3T3 fibroblasts. Proc. Natl. Acad. Sci. 86: 2888-2891.

Geissler, E.N., E.C. McFarland, and E.S. Russell. 1981. Analysis of pleiotropism at the dominant white-spotting $(W)$ locus of the house mouse: A description of ten new $W$ alleles. $G e$ netics 97: 337-361.

Geissler, E.N., M.A. Ryan, and D.E. Housman. 1988. The dominant-white spotting $(W)$ locus of the mouse encodes the c-kit proto-oncogene. Cell 55: 185-192.

Goddard, J.M., J.J. Weiland, and M.R. Capecchi. 1986. Isolation and characterization of Caenorhabditis elegans DNA sequences homologous to the v-abl oncogene. Proc. Natl. Acad. Sci. 83: 2172-2176.

Green, M.C. 1981. Genetic variants and strains of the laboratory mouse. Fischer-Verlag, Stuttgart, New York.

Gregory, R.J., K.L. Kammermeyer, W.S. Vincent III, and S.G. Wadsworth. 1987. Primary sequence and developmental expression of a novel Drosophila melanogaster src gene. Mol. Cell Biol. 7: 2119-2127.

Hafen, E., K. Basler, J.E. Edstrom, and G.M. Rubin. 1987. Sevenless, a cell specific homeotic gene of Drosophila, encodes a putative transmembrane receptor with a tyrosine kinase domain. Science 236: 55-63.

Hanks, S.K., A.M. Quinn, and T. Hunter. 1988. The protein kinase family: Conserved features and deduced phylogeny of the catalytic domains. Science 241: 42-52.

Hattori, M. and Y. Sakaki. 1986. Dideoxy sequencing method using denatured plasmid templates. Anal. Biochem. 152: $232-238$

Kadowaki, T., C.L. Bevins, A. Cama, K. Ojamaa, B. MarcusSamuels, H. Kadowaki, L. Beitz, C. McKeon, and S.I. Taylor. 1988. Two mutant alleles of the insulin receptor gene in a patient with extreme insulin resistance. Science 240: 787 790.

Kamps, M.P., S.S. Taylor, and B.M. Sefton. 1984. Direct evidence that oncogenic tyrosine kinase and cyclic AMP-dependent protein kinase have homologous ATP-binding sites. Nature 310: 589-592.

Karasuyama, H. and F. Melchers. 1988. Establishment of mouse cell lines which constitutively secrete large quantities of interleukin 2, 3, 4 or 5, using modified cDNA expression vectors. Eur. J. Immunol. 18: 97-104.

Klinkhamer, M.P., N.A. Groen, G.C.M. van der Zon, D. Lindhout, L.A. Sandkuyl, Krans, W. Möller, and J.A. Maassen 1989. A leucine-to-proline mutation in the insulin receptor in a family with insulin resistance. $E M B O ~ J .8: 2503-2507$.

Koland, J.G. and R.A. Cerione. 1988. Growth factor control of epidermal growth factor receptor kinase activity via an intramolecular mechanism. J. Biol. Chem. 263: 2230-2237.

Little, C.C. 1915. The inheritance of black-eyed white spotting in mice. Amer. Nat. 49: 727-740.

Little, C.C., and A.M. Cloudman. 1937. The occurrence of a dominant spotting mutation in the house mouse. Proc. Natl. Acad. Sci. 23: 535-537. 
Livneh, E., L. Glazer, D. Segal, J. Schlessinger, and B-Z. Shilo. 1985. The Drosophila EGF receptor gene homolog: Conservation of both hormone binding and kinase domains. Cell 40: $599-607$.

Nishida, Y., M. Hata, Y. Nishizuka, W.J. Rutter, and Y. Ebina. 1986. Cloning of a Drosophila cDNA encoding a polypeptide similar to the human insulin receptor precursor. Biochem. Biophys. Res. Commun. 141: 474-481.

Nocka, K., S. Majumder, B. Chabot, P. Ray, M. Cervone, A. Bernstein, P. Besmer. 1989. Expression of c-kit gene products in known cellular targets of $W$ mutations in normal and $W$ mutant mice-Evidence for an impaired c-kit kinase in mutant mice. Genes Dev. 3: 816-826.

Northwood, I.C. and R.J. Davis. 1988. Activation of the epidermal growth factor receptor tyrosine protein kinase in the absence of receptor oligomerization. I. Biol. Chem. 262: $7450-7453$

Odawara, M., T. Kadowaki, R. Yamamoto, Y. Shibasaki, K. Tobe, D. Accili, C. Bevins, Y. Mikami, N. Matsuura, Y. Akanuma, F. Takaku, S.I. Taylor, and M. Kasuga. 1989. Human diabetes associated with a mutation in the tyrosine kinase domain of the insulin receptor. Science 245: 66-68.

Price, J.V., R.J. Clifford, and T. Schupbach. 1989. The maternal ventralising locus torpedo is allelic to faint little ball, an embryonic lethal, and encodes the Drosophila EGF receptor homolog. Cell 56: 1085-1092.

Qiu, F., P. Ray, K. Brown, P.E. Barker, S. Jhanwar, F.H. Ruddle, P. Besmer. 1988. Primary structure of c-kit: Relationship with the CSF-1/PDGF receptor kinase family-oncogenic activation of $\mathrm{v}$-kit involves deletion of extracellular domain and $\mathrm{C}$ terminus. EMBO I. 7: 1003-1011.

Riggs, A.D. and P.A. Jones. 1983. 5-Methylcytosine, gene regulation and cancer. Adv. Cancer Res. 40: 1-30.

Roussel, M.F., J.R. Downing, C.W. Rettenmier, and C.J. Sherr. 1988. A point mutation in the extracellular domain of the human CSF-1 receptor (c-fms proto-oncogene product) activates its transforming potential. Cell 55: 979-988.

Russell, E.S. 1979. Hereditary anemias of the mouse: A review for geneticists. Adv. Genet. 20: 357-459.

Sadowski, I. and T. Pawson. 1987. Catalytic and non-catalytic domains of the fujinami sarcoma virus P130gag-tps protein-tyrosine kinase distinguished by the expression of $\mathrm{v}$-fps polypeptides in Escherichia coli. Oncogene 1: 181-191.

Schejter, E.D. and B-Z. Shilo. 1989. The Drosophila EGF receptor homolog (DER) gene is allelic to faint little ball, a locus essential for embryonic development. Cell 56: 10931104.

Schrader, J.W. 1986. The panspecific hemopoietin of activated T lymphocytes (interleukin3). Annu. Rev. Immunol. 4: $205-230$

Shtivelman, E., B. Lifshitz, R.P. Gale, B.A. Roe, and E. Canaani. 1986. Alternative splicing of RNAs transcribed from the human $a b l$ gene and from the $b c r-a b l$ fused gene. Cell 47: $277-284$.

Silvers, W.K. 1979. White-spotting, patch and rump-white. In The coat colors of mice: A model for gene action and interaction, pp. 206-241. Springer-Verlag, New York.

Sprenger, F., L.M. Stevens, and C. Nusslein-Volhard. 1989. The Drosophila gene torso encodes a putative receptor tyrosine kinase. Nature 338: 478-483.

Taira, M., M. Taira, N. Hashimoto, F. Shimada, Y. Suzuki, A. Kanatsuka, F. Nakamura, Y. Ebina, M. Tatibana, H. Makino, and S. Yoshida. 1989. Human diabetes associated with a deletion of the tyrosine kinase domain of the insulin receptor. Science 245: 63-66.

Takahashi, M. and G.M. Cooper. 1987. ret transforming gene encodes a fusion protein homologous to tyrosine kinases. Mol. Cell Biol. 7: 1378-1385.

Theiler, K. 1972. The house mouse. Springer-Verlag, Berlin, Heidelberg.

Tomlinson, A. and D.F. Ready. 1987. Cell fate in the Drosophila ommatidium. Dev. Biol. 123: 264-275.

Ullrich, A., L. Coussens, J.S. Hayflick, T.J. Dull, A. Gray, A.W Tam, J. Lee, Y. Yarden, T.A. Libermann, J. Schlessinger, J. Downward, E.L.V. Mayes, N. Whittle, M.D. Waterfield, and P.H. Seeburg, P.H. 1984. Human epidermal growth factor receptor cDNA sequence and aberrant expression of the amplified gene in A431 epidermoid carcinoma cells. Nature 309: 418-425.

Ullrich, A., J.R. Bell, E.Y. Chen, R. Herrera, L.M. Petruzzelli, T.J. Dull, A. Gray, L. Coussens, Y.-C. Liao, M. Tsubokawa, A. Mason, P.H. Seeburg, C. Grunfeld, O.M. Rosen, and J. Ramachandran. 1985. Human insulin receptor and its relationship to the tyrosine kinase family of oncogenes. Nature 313: $756-761$.

Ullrich, A., A. Gray, A.W. Tam, T. Yang-Feng, M. Tsubokawa, C. Collins, W. Henzel, T. Le Bon, S. Kathuria, E. Chen, S. Jacobs, U. Francke, J. Ramachandran, and Y. FujitaYamaguchi. 1986. Insulin-like growth factor I receptor primary structure: Comparison with insulin receptor suggests structural determinants that define functional specificity. $E M B O$ J. 5: 2503-2512.

Wang, R.Y-H., K.C. Kuo, C.W. Gehrke, L-H. Huang, and M. Ehrlich. 1982. Heat and alkali-induced deamination of 5methylcytosine and cytosine residues in DNA. Biochim. Biophys. Acta. 697: 371-377.

Weiner, D.B., J. Liu, J.A. Cohen, W.V. Williams, and M.I. Greene. 1989. A point mutation in the neu oncogene mimics ligand induction of receptor aggregation. Nature 339: $230-231$.

Weinmaster, G., M.J. Zoller, and T. Pawson. 1986. A lysine in the ATP-binding site of P130gag-fps is essential for protein-tyrosine kinase activity. $E M B O$ J. 5: 69-76.

Wiebauer, K. and J. Jiricny. 1989. In vitro correction of G-T mispairs to G-C pairs in nuclear extracts from human cells. Nature 339: 234-236.

Woolford, J., A. McAuliffe, and L.R. Rohrschneider. 1988. Activation of the feline cfms proto-oncogene: Multiple alterations are required to generate a fully transformed phenotype. Cell 55: 965-977.

Yamamoto, T., S. Ikawa, T. Akiyama, K. Semba, N. Nomura, N. Miyajima, T. Saito, K. Toyoshima. 1986. Similarity of protein encoded by the human c-erb-B-2 gene to epidermal growth factor receptor. Nature 319: 230-234.

Yarden, Y., and J. Schlessinger. 1987. EGF induces rapid reversible aggregation of the EGF-receptor. Biochemistry 26: $1443-1451$.

Yarden, Y. and A. Ullrich. 1988. Growth factor receptor tyrosine kinases. Annu. Rev. Biochem. 57: 443-478.

Yarden, Y., J.A. Escobedo, W-J. Kuang, T.L. Yang-Feng, T.O. Daniel, P.M. Tremble, E.Y. Chen, M.E. Ando, R.N. Harkins, U. Francke, V.A. Fried, A. Ullrich, and L.T. Williams. 1986. Structure of the receptor for platelet-derived growth factor helps define a family of closely related growth factor receptors. Nature 323: 226-232. 


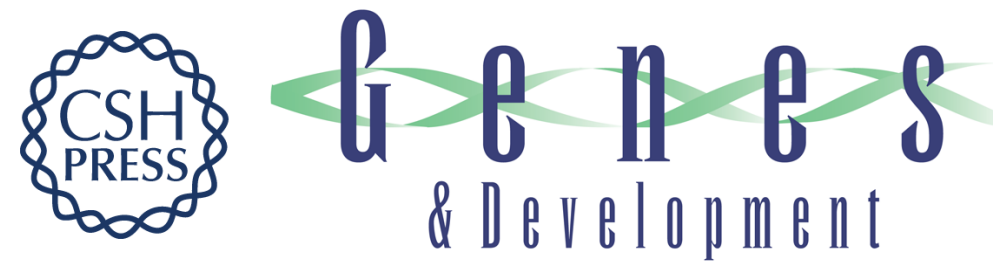

\section{W mutant mice with mild or severe developmental defects contain distinct point mutations in the kinase domain of the c-kit receptor.}

A D Reith, R Rottapel, E Giddens, et al.

Genes Dev. 1990, 4:

Access the most recent version at doi:10.1101/gad.4.3.390

References This article cites 64 articles, 20 of which can be accessed free at:

http://genesdev.cshlp.org/content/4/3/390.full.html\#ref-list-1

License

Email Alerting

Service

Receive free email alerts when new articles cite this article - sign up in the box at the top right corner of the article or click here.

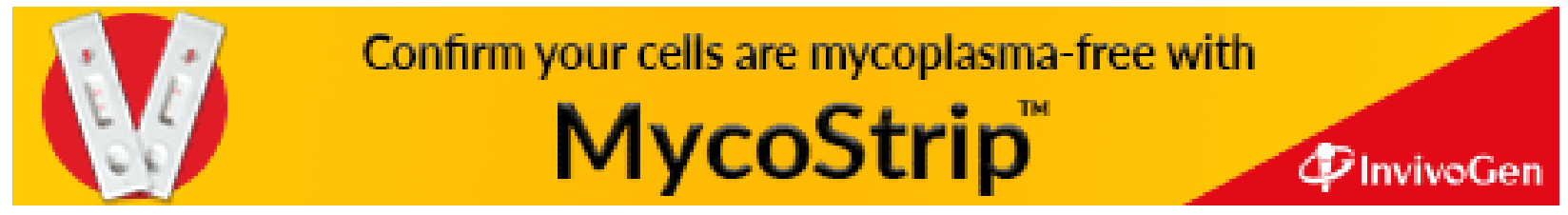

